\title{
Insect Management for Potatoes 1
}

\section{S. E. Webb²}

Chewing insects can cause serious yield and quality losses in potatoes by feeding on the leaves, stems or tubers. Sucking insects can cause direct losses from feeding and indirect losses by transmitting viral diseases. The most important of these insects are described below. A table at the end of the chapter lists insecticides currently registered for potatoes.

\section{Colorado Potato Beetle, Leptinotarsa decemlineata}

\section{Description}

Adult beetles have 10 lengthwise black stripes on yellow-orange wing covers and are approximately $3 / 8$ to $1 / 2$ inch long. They are stout and strongly convex in shape. The yellow-orange spindle-shaped eggs are laid in clusters of 10 to 30 on the undersides of leaves. They are very similar to ladybird beetle eggs but are larger. The larvae are humpbacked, red to orange, and have two rows of black spots on each side of their soft bodies.

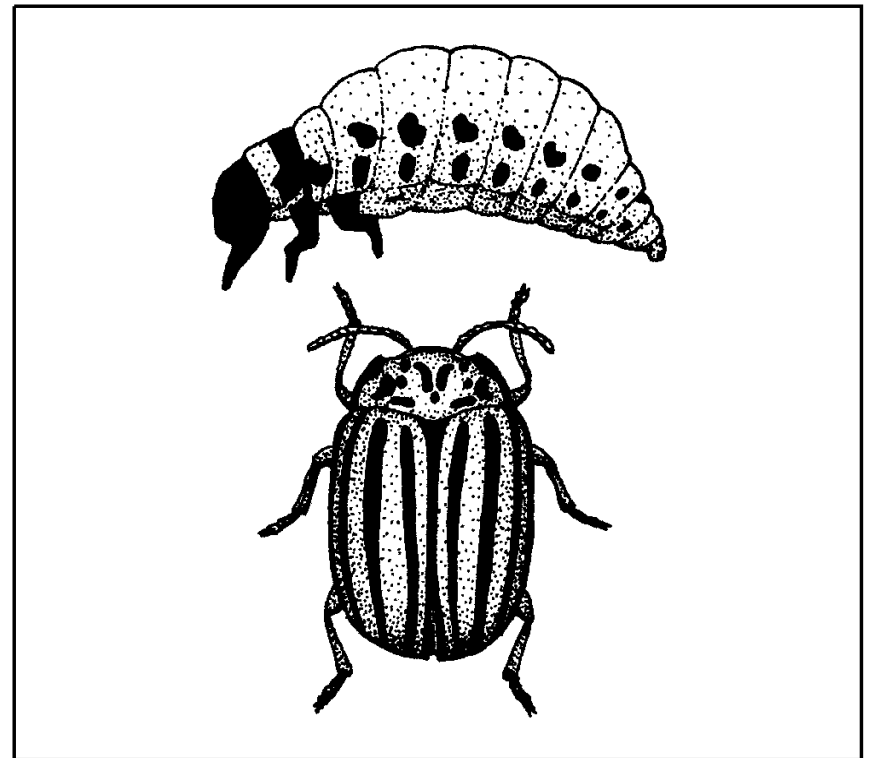

Figure 1. Colorado potato beetle.

\section{Biology}

The major food plant of the Colorado potato beetle is potato. Other crop hosts include tomato and eggplant. Wild hosts found in Florida include horsenettle and groundcherry. Horsenettle is found mainly in North Central and North Florida, which is also where the beetle is generally found. Adults

1. This document is ENY-469 (which replaces ENY-438), one of a series of the Entomology \& Nematology Department, Florida Cooperative Extension Service, Institute of Food and Agricultural Sciences, University of Florida. Published: November 2001. Revised: August 2005. For more publications related to horticulture/agriculture, please visit the EDIS Website at http://edis.ifas.ufl.edu/.

2. S. E. Webb, associate professor, Entomology and Nematology Department, Cooperative Extension Service, Institute of Food and Agricultural Sciences, University of Florida, Gainesville, 32611-0640.

The use of trade names in this publication is solely for the purpose of providing specific information. UF/IFAS does not guarantee or warranty the products named, and references to them in this publication does not signify our approval to the exclusion of other products of suitable composition. All chemicals should be used in accordance with directions on the manufacturer's label. Use pesticides safely. Read and follow directions on the manufacturer's label. 
overwinter in fields where they developed as larvae or in uncultivated areas adjacent to fields. They can also overwinter in wooded areas. Only a small proportion of a population leaves its field of origin by flying. Each adult female can produce about 450 eggs. Larvae, which pass through 4 instars, are generally found near the top of the plant and they seldom move far from the plant on which they hatch unless all the leaves are eaten. About two-thirds of all feeding by larvae occurs in the fourth or last instar. When the larvae have completed their development they enter an inactive pupal stage in the soil. After 5 to 7 days, adults emerge and begin to feed on the potato plants. Under ideal conditions, the life cycle can be completed in three weeks. Potato beetles are unaffected by high concentrations of toxic glycoalkaloids, the naturally occurring bitter compounds in potatoes. The efficient detoxification system of the beetle may also play a part in detoxifying insecticides and in the development of insecticide resistance.

\section{Damage}

The Colorado potato beetle is a significant problem only in North Florida production regions. High numbers of late instar larvae can defoliate plants. Yield loss is greatest if heavy damage occurs during tuber formation. Bacterial ring rot and potato spindle tuber disease, which are easily spread by mechanical means, can also be transmitted by Colorado potato beetle.

Table 1. Management options for Colorado potato beetle.

\begin{tabular}{||l|l||}
\hline \multicolumn{1}{||}{$\begin{array}{c}\text { Management } \\
\text { Option }\end{array}$} & \multicolumn{1}{c||}{ Recommendation } \\
\hline $\begin{array}{l}\text { Scouting/ } \\
\text { Thresholds }\end{array}$ & $\begin{array}{l}\text { Examine about 50 plants or main } \\
\text { stems along a V-shaped path } \\
\text { extending at least 100 yards into } \\
\text { the field and intersecting 50 to 100 } \\
\text { rows. Check field edges early in } \\
\text { the season. Thresholds used in } \\
\text { New England for applying } \\
\text { broad-spectrum insecticides are } \\
200 \text { or more small larvae per } 50 \\
\text { plants or 30 large larvae. For } \\
\text { control with Bt, a threshold of } 75 \text { or } \\
\text { fewer small larvae is used. Bt is } \\
\text { not effective for control of large } \\
\text { larvae. }\end{array}$ \\
\hline \hline
\end{tabular}

Table 1. Management options for Colorado potato beetle.

\begin{tabular}{||l|l||}
\hline \multicolumn{1}{||c||}{$\begin{array}{c}\text { Management } \\
\text { Option }\end{array}$} & \multicolumn{1}{c|}{ Recommendation } \\
\hline Notes & $\begin{array}{l}\text { More damage can be tolerated } \\
\text { before and after tuber formation. }\end{array}$ \\
\hline $\begin{array}{l}\text { Cultural } \\
\text { Practices }\end{array}$ & $\begin{array}{l}\text { Crop rotation is essential and } \\
\text { effective for delaying and reducing } \\
\text { the initial infestation. Fields should } \\
\text { be at least several hundred yards } \\
\text { from areas previously infested with } \\
\text { beetles. }\end{array}$ \\
\hline Natural & $\begin{array}{l}\text { Lady beetles, predacious } \\
\text { stinkbugs, parasitic flies, and fungi } \\
\text { can help reduce populations. } \\
\text { Conserve by limiting applications } \\
\text { of broad-spectrum insecticides. }\end{array}$ \\
\hline Resistant & $\begin{array}{l}\text { Genetically engineered to contain } \\
\text { Bt toxin genes }\end{array}$ \\
\hline \hline
\end{tabular}

\section{Wireworms, Melanotus communis, Conoderus spp.}

\section{Description}

Wireworms are the larvae of the click beetle. They are shiny, slender, hard-bodied and yellow to brown. Adults are large brown beetles that make a clicking sound when they try to right themselves after being turned over.

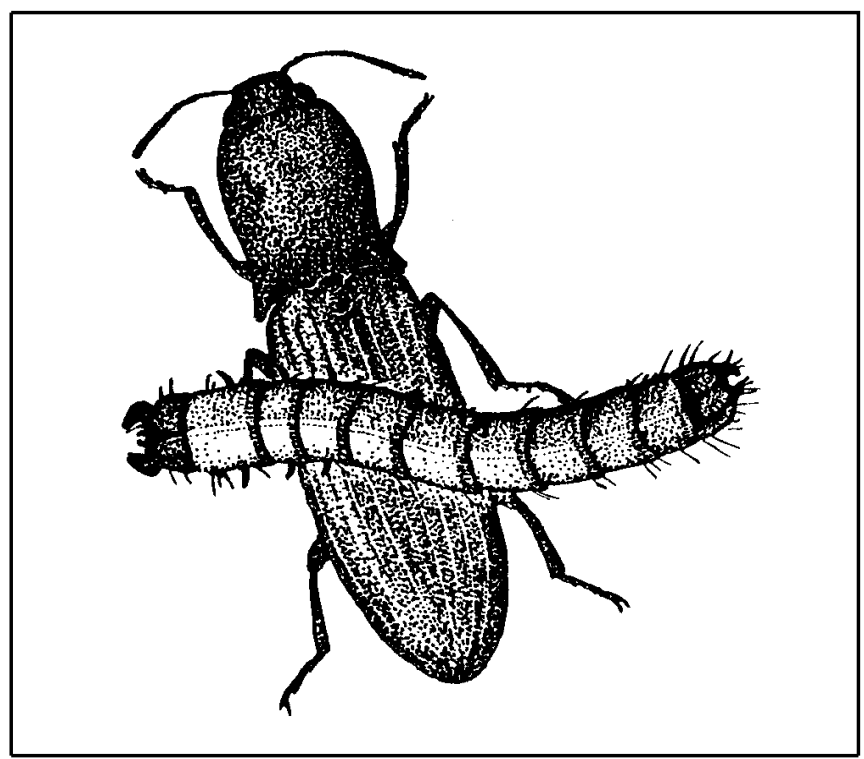

Figure 2. Wireworm larva and adult. 


\section{Biology}

Depending on species and soil temperature, wireworm larvae can take from 1 to 5 years to develop. Corn wireworm (Melanotus communis), common in Florida, may complete its development in 2 to 3 years in South Florida. Most flight activity occurs in May and June. Females lay eggs in cracks or crevices or burrow into the soil. Larvae tend to move deeper as soil temperatures become hotter and move closer to the soil surface when it is cooler. If temperatures drop further, larvae will again move deeper into the soil. Other wireworms found in Florida (Conoderus spp.) can complete their development in a year or less, resulting in up to three generations per year in South Florida. These species tend to stay close to the soil surface.

\section{Damage}

The adult wireworms do not attack potatoes, however the larvae ("wireworms") feed on potato seed pieces and developing tubers. Wounds to seed pieces allow disease organisms, such as fungi and bacteria, to enter. The greatest damage occurs when larvae tunnel into developing tubers, reducing their quality and value. Damaged tubers are often malformed.

Table 2. Management options for wireworms.

\begin{tabular}{||l|l||}
\hline \multicolumn{1}{|c||}{$\begin{array}{c}\text { Management } \\
\text { Option }\end{array}$} & \multicolumn{1}{c||}{ Recommendation } \\
\hline $\begin{array}{l}\text { Scouting/ } \\
\text { Threshold }\end{array}$ & $\begin{array}{l}\text { Determine population density 4 to } \\
5 \text { weeks before planting. Baits are } \\
\text { the easiest method. Small } \\
\text { amounts of corn, oats, or wheat } \\
\text { can be enclosed in a mesh bag } \\
\text { and buried 4 to 6 inches deep in 4 } \\
\text { or 5 sites per acre for two to three } \\
\text { weeks. If soil is below 45 to 50 F, } \\
\text { covering the baited area with a } \\
\text { clear plastic sheet will help warm it } \\
\text { and increase wireworm activity. } \\
\text { One wireworm per bait station } \\
\text { justifies treatment with a soil } \\
\text { insecticide. }\end{array}$ \\
\hline Notes & $\begin{array}{l}\text { To determine if a sidedress } \\
\text { treatment of insecticide is needed } \\
\text { after planting, dig seed pieces at } \\
\text { random throughout the field as } \\
\text { shoots emerge to check for } \\
\text { wireworm damage. }\end{array}$ \\
\hline \hline
\end{tabular}

Table 2. Management options for wireworms.

\begin{tabular}{||l|l||}
\hline \hline \multicolumn{1}{||c|}{$\begin{array}{c}\text { Management } \\
\text { Option }\end{array}$} & \multicolumn{1}{c|}{ Recommendation } \\
\hline Enemies & $\begin{array}{l}\text { Not well known, do not seem to be } \\
\text { important. A fungus and a parasitic } \\
\text { wasp have been reported. }\end{array}$ \\
\hline Site Selection & $\begin{array}{l}\text { If possible, avoid areas with a } \\
\text { history of wireworm problems. }\end{array}$ \\
\hline Cultural & $\begin{array}{l}\text { Avoid planting potatoes in areas } \\
\text { that have been in cereals or } \\
\text { grasses. In South Florida, delaying } \\
\text { the planting of } \\
\text { sorghum-sudangrass cover crops } \\
\text { until July (well after harvest of } \\
\text { winter potatoes) helps keep } \\
\text { wireworm populations low. }\end{array}$ \\
\hline \hline
\end{tabular}

\section{Leafminers}

\section{Description and Biology}

The adult is a small fly, approximately $1 / 8$ inch long, with a black head, yellow between the eyes, a black thorax and a tube-like "ovipositor" at the end of the abdomen used to puncture the upper leaf surface for egg laying. The white, oval egg is inserted in the leaf tissue, but many punctures (called stipples) are used by the adult for feeding and do not contain eggs. The larva, a yellow maggot with black, sickle-shaped mouth hooks, feeds between the upper and lower leaf surface for approximately seven days, leaving a serpentine mine containing a string of black frass (fecal matter). The mature larva exits from the mine and falls to the ground where it molts to a pupa within a golden brown, barrel-shaped, and ribbed puparium from which the adult emerges in seven to 14 days. Generation time is 15 to 28 days depending upon temperature.

\section{Damage}

Leafminer damage is only foliar, caused by serpentine mines carved in leaves by feeding leafminer larvae. Heavy damage can reduce photosynthesis and cause leaf desiccation and abscission. 


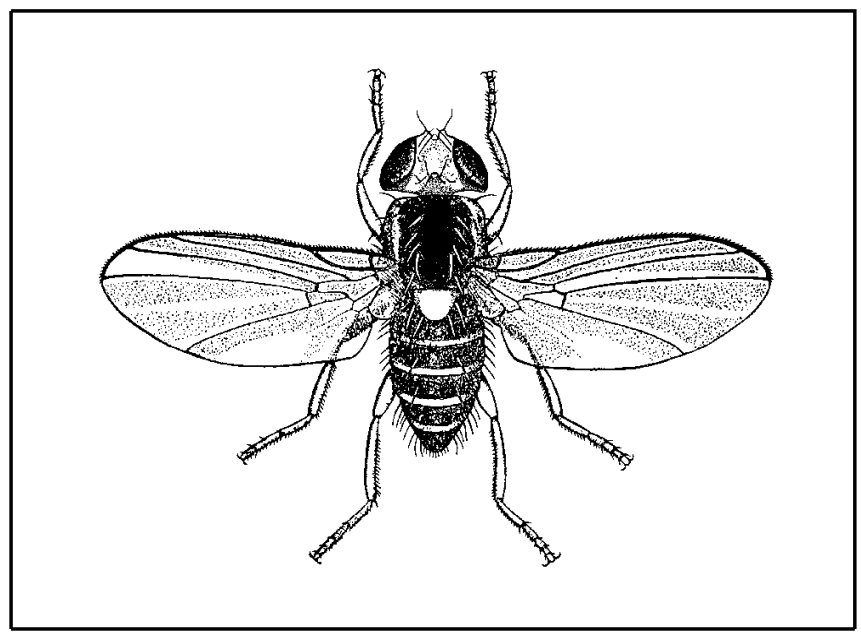

Figure 3. Vegetable leafminer.

Table 3. Management options for leafminers.

\begin{tabular}{||l|l||}
\hline \multicolumn{1}{|c||}{$\begin{array}{c}\text { Management } \\
\text { Options }\end{array}$} & \multicolumn{1}{c||}{ Recommendation } \\
\hline $\begin{array}{l}\text { Scouting/ } \\
\text { Threshold }\end{array}$ & $\begin{array}{l}\text { Sampling can be done at the same } \\
\text { time that plants are examined for } \\
\text { Colorado potato beetle. No } \\
\text { thresholds have been determined } \\
\text { for leafminers on potatoes, } \\
\text { however. }\end{array}$ \\
\hline Note(s) & $\begin{array}{l}\text { Insecticides applied for leafminer } \\
\text { control should target small larvae } \\
\text { for best results. }\end{array}$ \\
\hline Natural & $\begin{array}{l}\text { A number of parasitic wasps attack } \\
\text { vegetable and serpentine } \\
\text { leafminers in Florida and may } \\
\text { provide high levels of mortality, } \\
\text { especially late in the season. } \\
\text { Therefore, insecticides with low or } \\
\text { no toxicity to leafminer parasites } \\
\text { should be selected for controlling } \\
\text { leafminers and other pests. }\end{array}$ \\
\hline \hline
\end{tabular}

\section{Flea Beetle, Epitrix hirtipennis, others}

\section{Description}

Tobacco flea beetle (Figure 4) is a fairly typical flea beetle pest of potatoes in Florida. Adults are very small, $1 / 12$ to $1 / 20$ of an inch long. They are reddish-yellow with a brown abdomen and a brown patch crossing the wing covers. Eggs are elongate and slightly pointed at one end. They change from white to lemon yellow as they get close to hatching. Larvae are whitish except for their yellow or yellow-brown heads and reach a length of $1 / 6$ of an inch long.

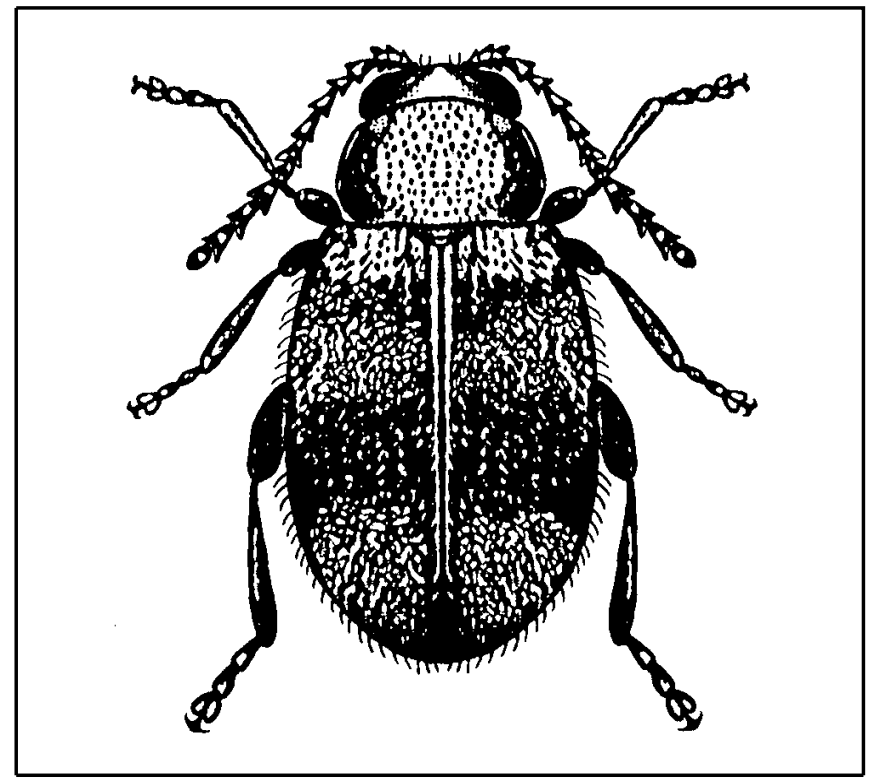

Figure 4. Tobacco flea beetle.

\section{Biology}

Tobacco flea beetle feeds on tobacco, potato, tomato, eggplant and other plants in the family Solanaceae. In Florida, at least 4 generations a year can develop. Beetles overwinter as adults under plant debris. If the weather is warm enough, they may remain active all winter. Eggs are laid in the soil near the base of the host plant, in clusters of 5 or 6 . Overwintering females can produce up to 200 eggs with later generations producing about 100 eggs per female. Larvae develop through three instars and feed mainly on fine roots near the soil surface. They pupate near the soil surface also. Adults feed on leaves.

\section{Damage}

The adult beetle eats small holes partly or completely through the leaves, resulting in the formation of many small "shot holes" in the leaves. Seedlings are most vulnerable to severe damage. Feeding wounds may serve as a point of entry for pathogens.

Table 4. Management options for flea beetles.

\begin{tabular}{||l|l||}
\hline $\begin{array}{c}\text { Management } \\
\text { Options }\end{array}$ & \multicolumn{1}{c||}{ Recommendation } \\
\hline $\begin{array}{l}\text { Scouting/ } \\
\text { Threshold }\end{array}$ & $\begin{array}{l}\text { Adults can be monitored with } \\
\text { yellow sticky traps or by sweeping, } \\
\text { but no thresholds for treatment } \\
\text { have been developed. }\end{array}$ \\
\hline \hline
\end{tabular}


Table 4. Management options for flea beetles.

\begin{tabular}{||l|l||}
\hline \hline \multicolumn{1}{|c||}{$\begin{array}{c}\text { Management } \\
\text { Options }\end{array}$} & \multicolumn{1}{c||}{ Recommendation } \\
\hline Note(s) & $\begin{array}{l}\text { Systemic insecticides are useful } \\
\text { for protecting seedlings in areas } \\
\text { where flea beetles are a } \\
\text { consistent problem. }\end{array}$ \\
\hline $\begin{array}{l}\text { Natural } \\
\text { Enemies }\end{array}$ & $\begin{array}{l}\text { General predators such as } \\
\text { big-eyed bug, a parasitoid wasp, } \\
\text { and a nematode, Howardula } \\
\text { dominicki }\end{array}$ \\
\hline Cultural & No effective methods available. \\
\hline Practices & \\
\hline \hline
\end{tabular}

\section{Leafhopper, Empoasca fabae and close relatives}

\section{Description}

The adult potato leafhopper (Figure 5) is pale green with a row of white spots just behind its head. It has a slender body form and is about $1 / 8$ to $1 / 7$ inch long. Eggs are transparent to pale yellow and are inserted into the veins and petioles of leaves. Young nymphs are very small (about $1 / 25$ inch). Wing pads develop from the third through fifth instars.

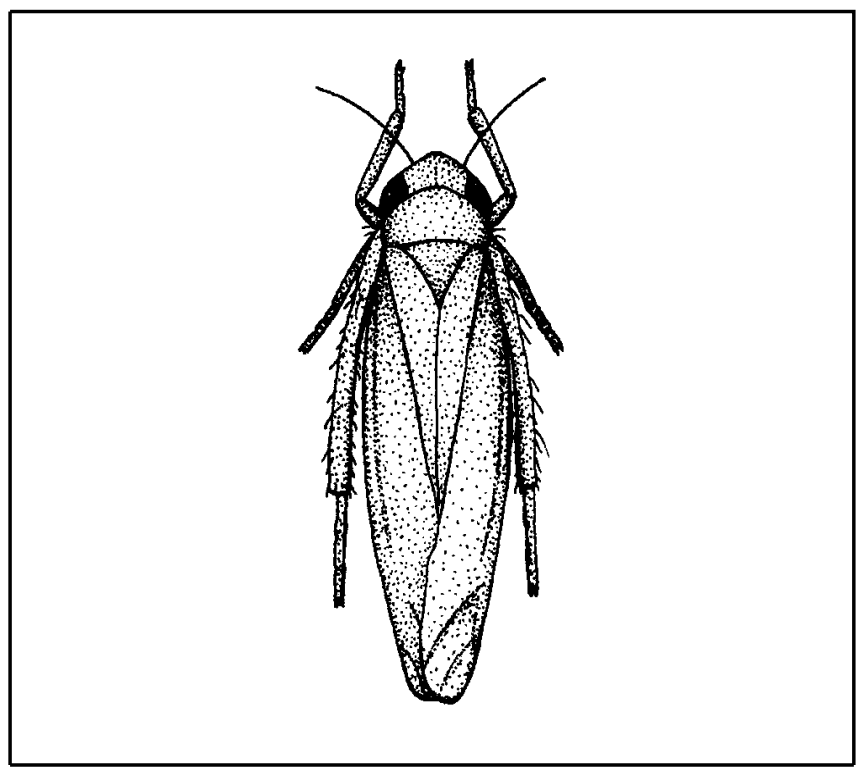

Figure 5. Leafhopper.

\section{Biology}

The adult potato leafhopper overwinters in Gulf Coast States, including Florida, and disperses northward. In Florida, it can complete six generations a year. It feeds on many wild and cultivated plants, but potato is a particularly good host plant. Females can produce 200 to 300 eggs. These hatch in from 7 to 20 days depending on temperature. The average developmental time for nymphs is about 15 days. Adults can live from one to two months. Leafhoppers seem to have few effective natural enemies.

\section{Damage}

Leafhopper damage (hopper burn) late in the season is often confused with maturity of the plants (damaged leaves first turn brown along the margins but remaining foliage is often green). The adults and nymphs attack the underside of the leaves and suck the sap. They secrete a toxin into the plant as they feed. This causes the leaves to curl, yellow, and exhibit hopper burn symptoms. Plants may be stunted and yields reduced.

\section{Aphids, Myzus persicae and Macrosiphym euphorbiae}

\section{Description}

Aphids are small, soft-bodied insects that reproduce rapidly and feed on plant sap. In Florida, green peach aphid (Myzus persicae) (Figure 6) is the most common aphid on potatoes, but potato aphid (Macrosiphum euphorbiae) (Figure 7) can also be found. Aphids occur in both winged and wingless forms. The mature wingless form of green peach aphid is egg-shaped, the tubercles at the base of the antennae are prominent and point inward, and the cornicles, tube-like structures on the back of the aphid, are long and unevenly swollen. They can range in color from light green to pink to almost translucent. Potato aphid is larger and more elongated with longer, straight cornicles and can be green, yellow, or pink. The pink form is common in the Hastings area. Its antennal tubercles point outward.

\section{Biology}

In Florida, aphids can reproduce without mating all year, as long as host plants are available. They give birth to nymphs rather than laying eggs and their offspring can be producing nymphs of their own in 7 to 10 days depending on temperature. High populations can develop very quickly as plants get 


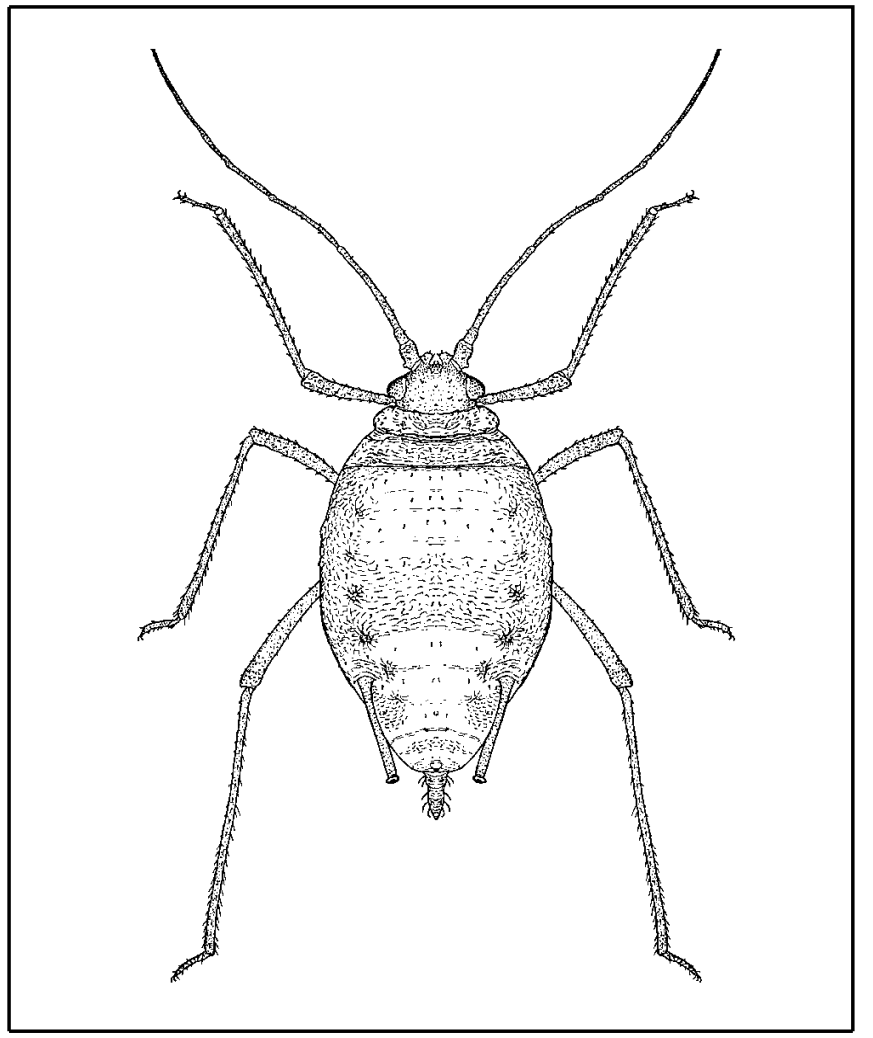

Figure 6. Wingless green peach aphid.

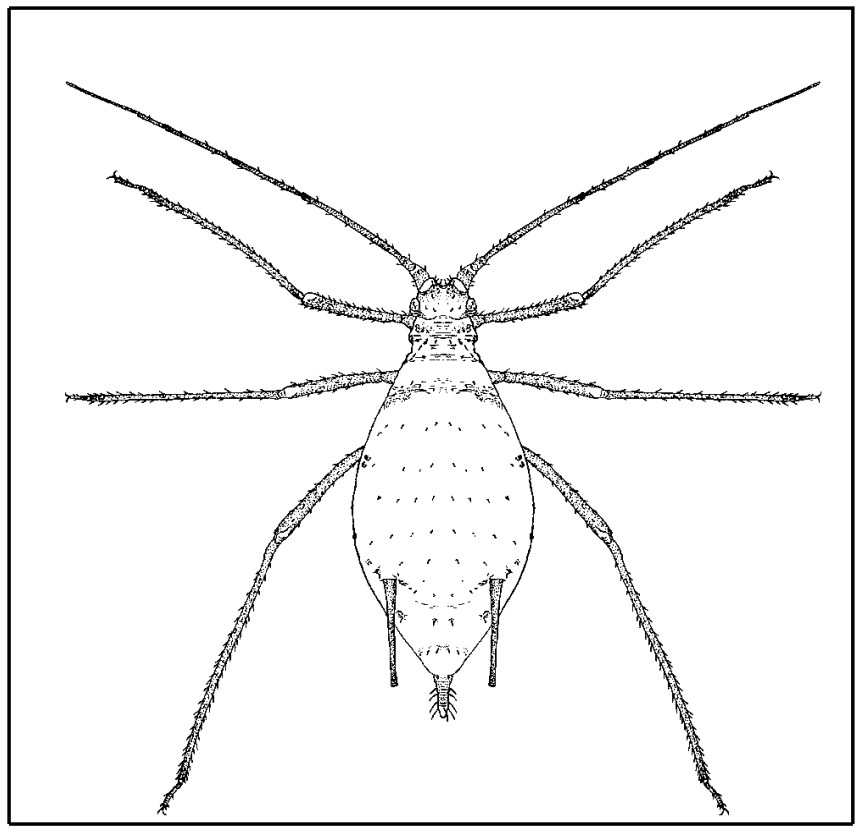

Figure 7. Potato aphid.

crowded. Winged forms develop and fly to new host plants. Aphids have many natural enemies, both general predators such as lacewing and ladybeetle larvae, and more specific parasitoid wasps. Fungi can kill large numbers of aphids in a short period of time.

\section{Damage}

Aphids cause damage by sucking juices from the underside of leaves on the above ground portion of the potato plant. Feeding by potato aphids can cause distortion of young leaves and the dying back of the shoot or stem. Green peach aphid is more common in Florida. Early season infestation is the most damaging and can result in yield loss. Green peach aphid is also an excellent virus vector, transmitting viruses from plant to plant. At this time, potato leafroll virus and potato virus $\mathrm{Y}$, the most important of the aphid-transmitted plant viruses affecting potato, are not common in Florida potato fields. Currently, aphids are managed with systemic insecticides applied at planting.

\section{Caterpillar-type Pests (beet armyworm, fall armyworm, southern armyworm, cutworms, cabbage looper, etc.)}

Larvae of moths can damage and occasionally defoliate potato plants. Two examples are described below.

Cabbage looper, Trichoplusia ni (Hübner) (Figure 8), feeds on a variety of crops. The adults (Figure 9) are night-flying moths with brown, mottled forewings marked in the center with a small, silver figure eight. They lay their eggs (small, ridged, round, greenish-white) singly on both upper and lower leaf surfaces. The eggs hatch into larvae that are green with white stripes running the length of their bodies. The caterpillar has three pairs of slender legs near its head and then three pairs of thick prolegs near the end of its body. It moves in a characteristic looping motion, alternately stretching forward and arching its back as it brings the back prolegs close to its front legs. After feeding for two to four weeks, the caterpillar, about 1.25 inches long when fully grown, spins a cocoon and pupates. The adults emerge 10 days to two weeks later. There can be several generations per year depending on climate. They tend to feed on older leaves.

Beet armyworm, Spodoptera exigua (Hübner) (Figure 10), also feeds on many crops and weeds. The highly mobile adult moth (Figure 11) has dark 


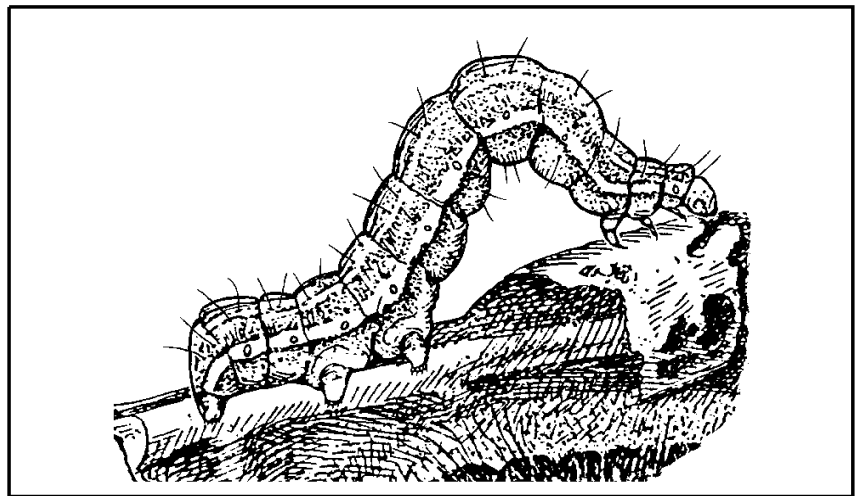

Figure 8. Cabbage looper larva.

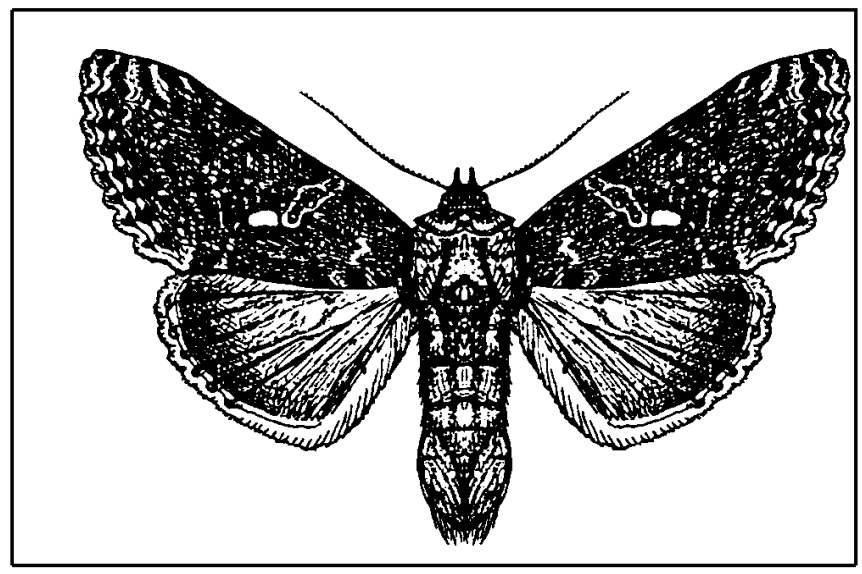

Figure 9. Cabbage looper adult male.

forewings with mottled lighter markings and hind wings thinly covered with whitish scales. Each female can lay over 600 eggs, generally in masses of about 100 on the undersides of leaves in the lower plant canopy. Very young caterpillars feed in groups, and then disperse as they grow older (third instar). The dull green caterpillars have wavy, light-colored stripes lengthwise down the back and broader stripes on each side. After feeding from one to three weeks, they construct a cocoon and pupate, emerging as adults about one week later. Beet armyworm survives the winter in South Florida and can complete many generations a year there. From South Florida, adults migrate into North Florida and other parts of the Southeast.

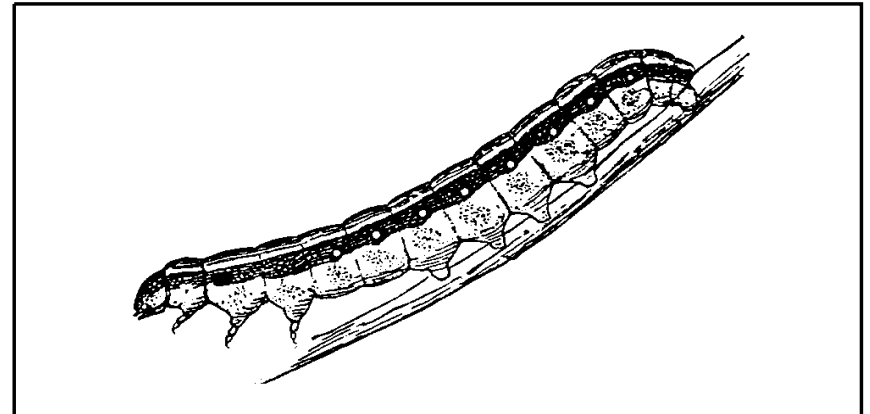

Figure 10. Beet armyworm larva.

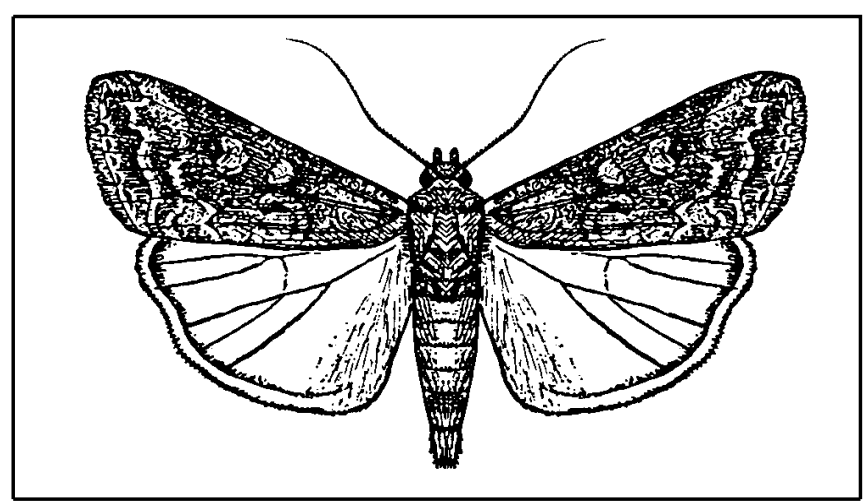

Figure 11. Beet armyworm adult.

Table 5. Management options for caterpillar-type pests.

\begin{tabular}{||l|l||}
\hline \hline $\begin{array}{c}\text { Management } \\
\text { Option }\end{array}$ & \multicolumn{1}{|c||}{ Recommendation } \\
\hline Thresholds & $\begin{array}{l}\text { Fields should be monitored for the } \\
\text { presence of caterpillars and } \\
\text { feeding damage. }\end{array}$ \\
\hline Note(s) & $\begin{array}{l}\text { Many different forms of Bacillus } \\
\text { thuringiensis are available that are } \\
\text { highly specific for caterpillar pests } \\
\text { and will not harm beneficial insects. } \\
\text { However, only small caterpillars are } \\
\text { highly susceptible. }\end{array}$ \\
\hline Natural & $\begin{array}{l}\text { In Florida, cabbage loopers have } \\
\text { been found naturally infected with } \\
\text { an insect virus and granulate } \\
\text { cutworm has been found infected } \\
\text { with a protozoan. A virus and fungal } \\
\text { pathogens also infect beet } \\
\text { armyworm. Parasitoids, both } \\
\text { wasps and tachinid flies, attack } \\
\text { beet armyworm. A number of small } \\
\text { wasps and a tachinid fly parasitize } \\
\text { caterpillars or eggs of cabbage } \\
\text { looper. Predaceous bugs, wasps, } \\
\text { green lacewings, and spiders may } \\
\text { consume eggs and small } \\
\text { caterpillars. }\end{array}$ \\
\hline \hline
\end{tabular}




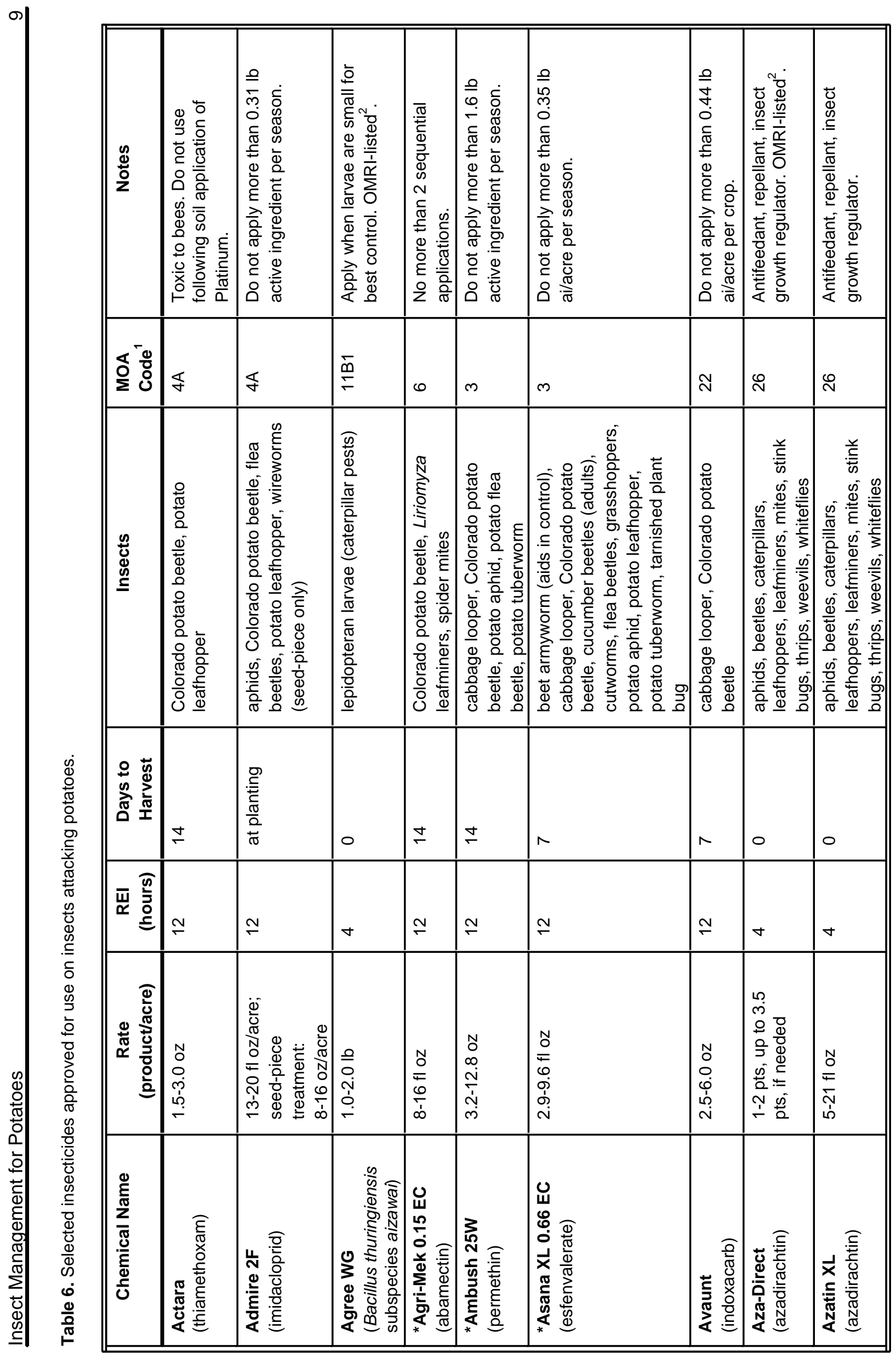




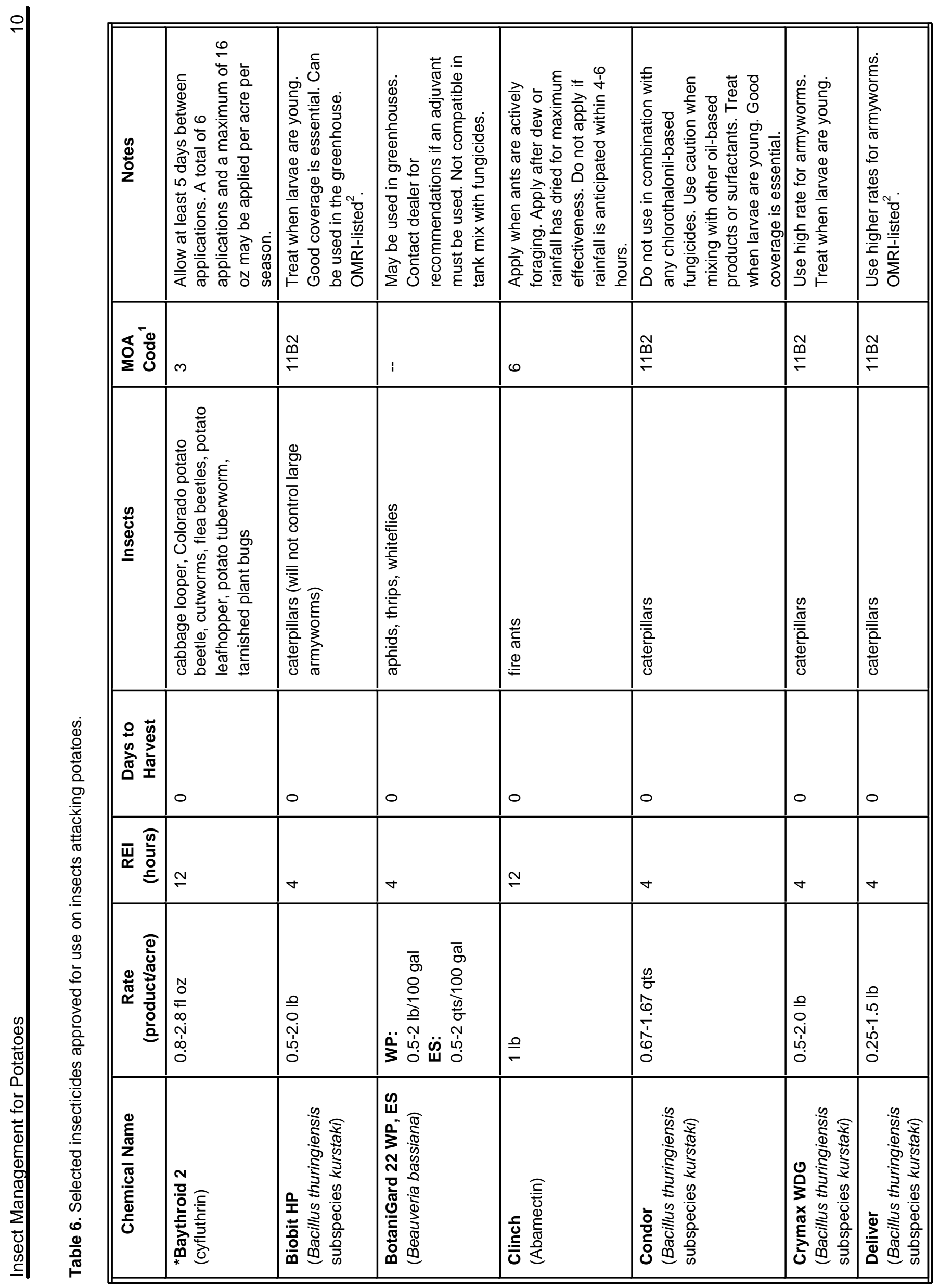




\begin{tabular}{|c|c|c|c|c|c|c|c|c|c|}
\hline $\begin{array}{l}\mathscr{y} \\
\stackrel{0}{0} \\
\text { zo }\end{array}$ & 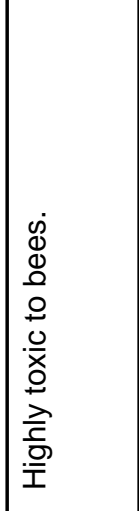 & 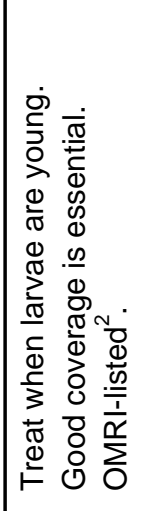 & 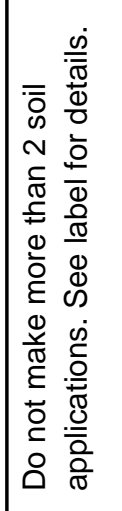 & 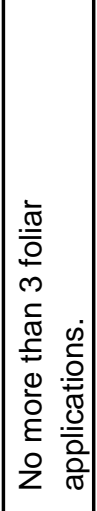 & 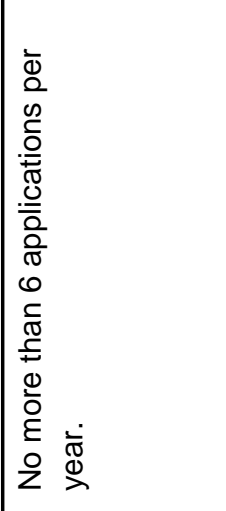 & 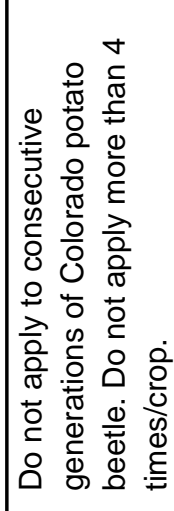 & 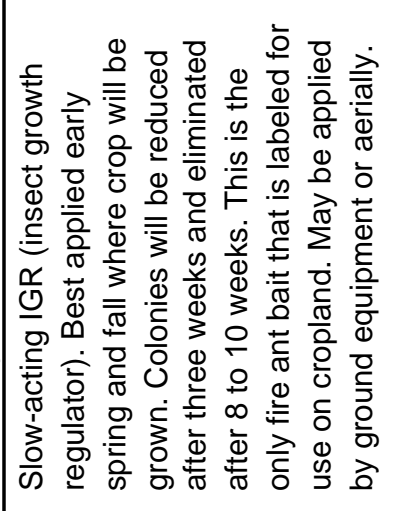 & 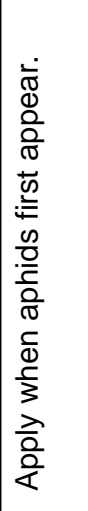 & 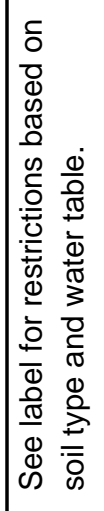 \\
\hline 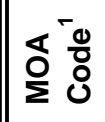 & $\dddot{m}$ & $\underset{\stackrel{\varpi}{\rightleftharpoons}}{\stackrel{\varpi}{\rightleftharpoons}}$ & $\dddot{m}$ & $\stackrel{\oplus}{\sim}$ & $\sim$ & م & $\leqslant$ & ळ & $\$$ \\
\hline 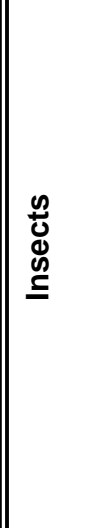 & 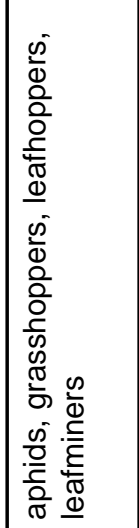 & 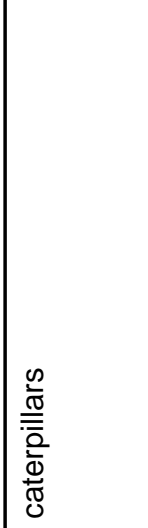 & 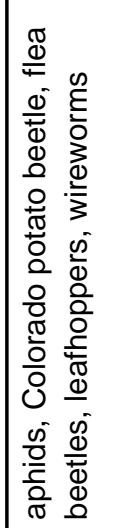 & 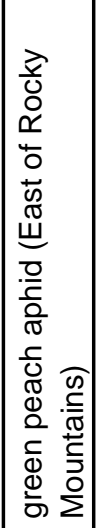 & 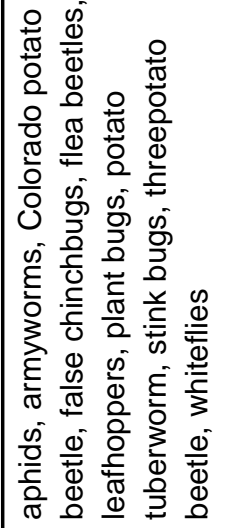 & 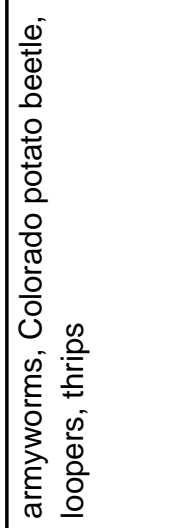 & 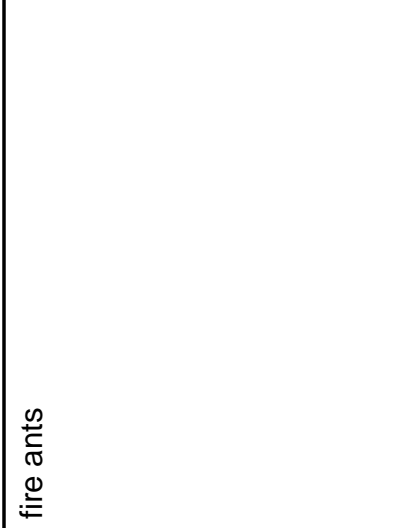 & 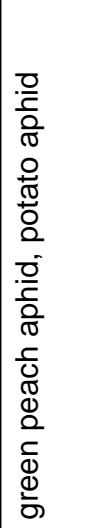 & 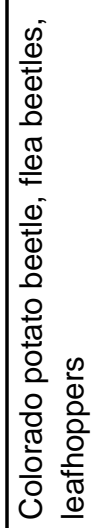 \\
\hline 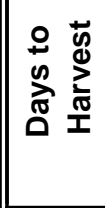 & 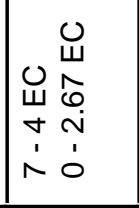 & 0 & $\mid$\begin{tabular}{|l}
$\overline{\bar{\sigma}}$ \\
$\dot{\omega}$ \\
$\hat{\rho}$
\end{tabular} & 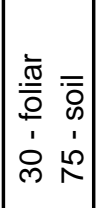 & - & $\wedge$ & 0 & $\stackrel{\nabla}{ }$ & 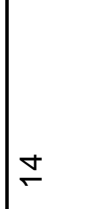 \\
\hline 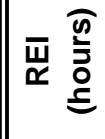 & $\stackrel{\infty}{\leftrightarrow}$ & $\theta$ & \multicolumn{2}{|l|}{$\stackrel{\infty}{4}$} & $\mathbb{N}$ & $\theta$ & $\nabla$ & $\cong$ & $\stackrel{\infty}{q}$ \\
\hline 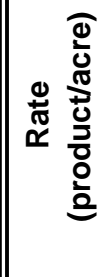 & 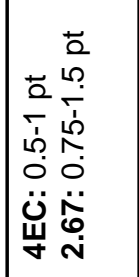 & 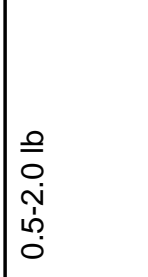 & 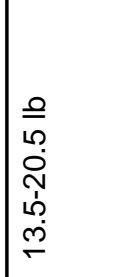 & $\begin{array}{l}\vec{a} \\
\stackrel{a}{d} \\
\stackrel{d}{n}\end{array}$ & 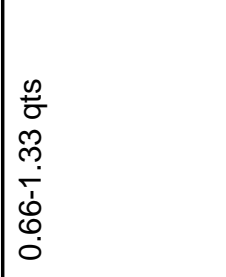 & \begin{tabular}{|l}
0 \\
0 \\
0 \\
\\
\\
\end{tabular} & 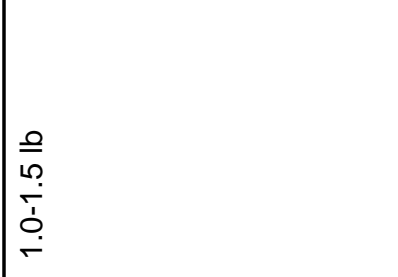 & $\begin{array}{l}N \\
o \\
\stackrel{N}{N} \\
\text { N }\end{array}$ & 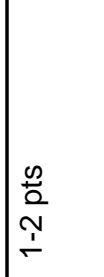 \\
\hline 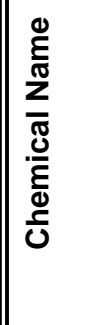 & 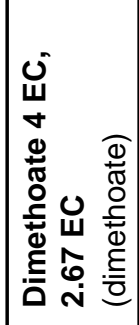 & 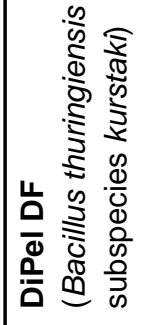 & 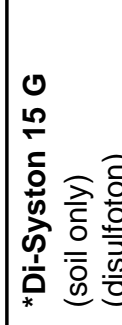 & 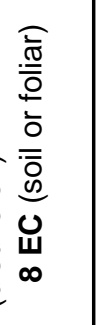 & 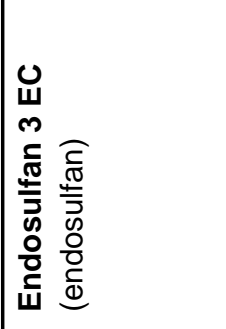 & 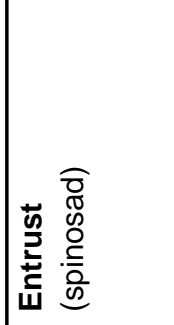 & 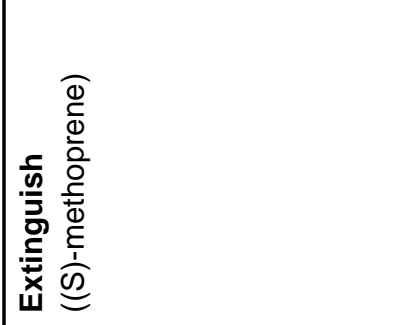 & 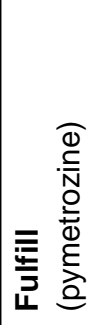 & 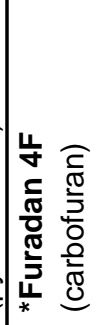 \\
\hline
\end{tabular}




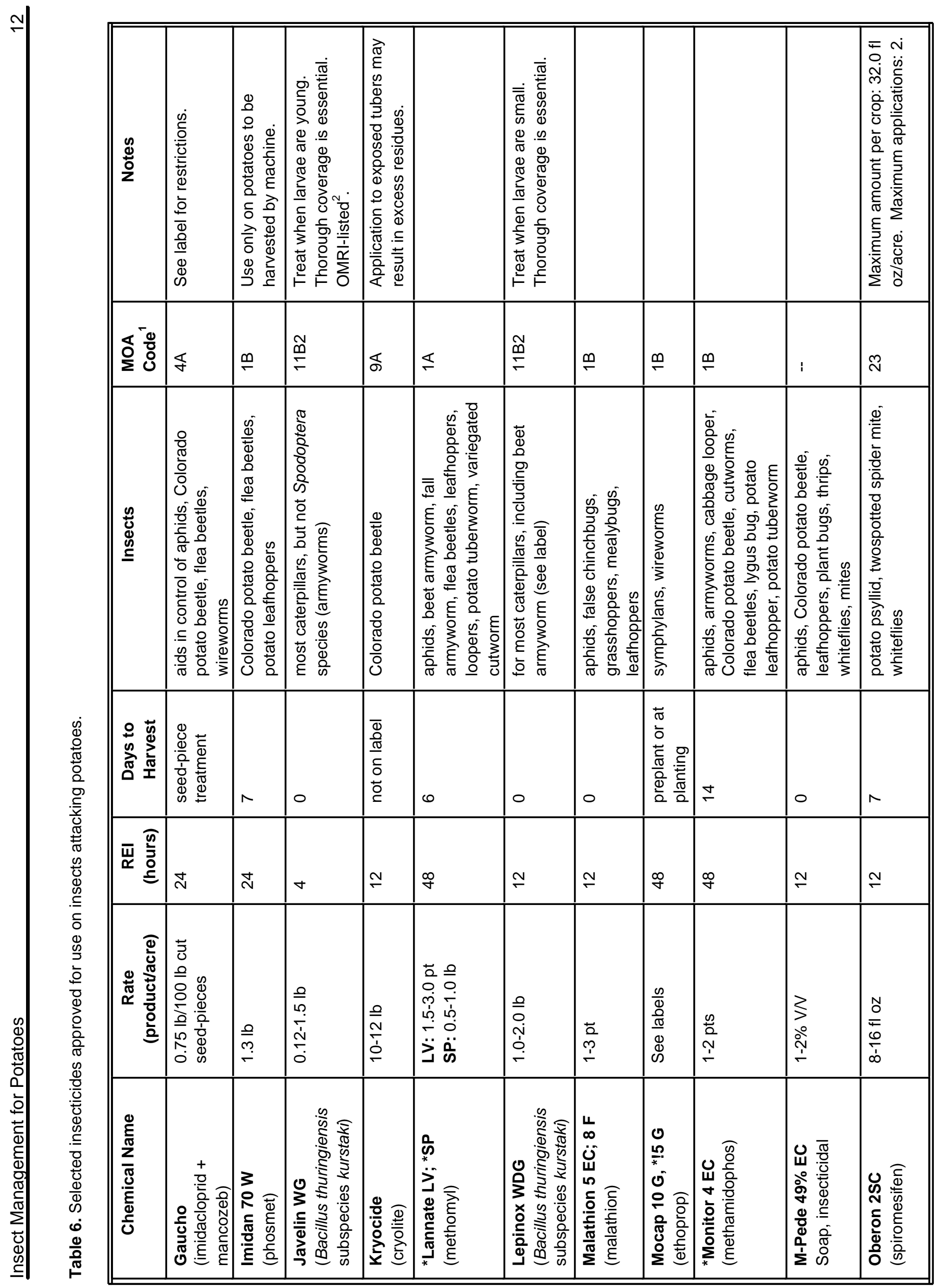




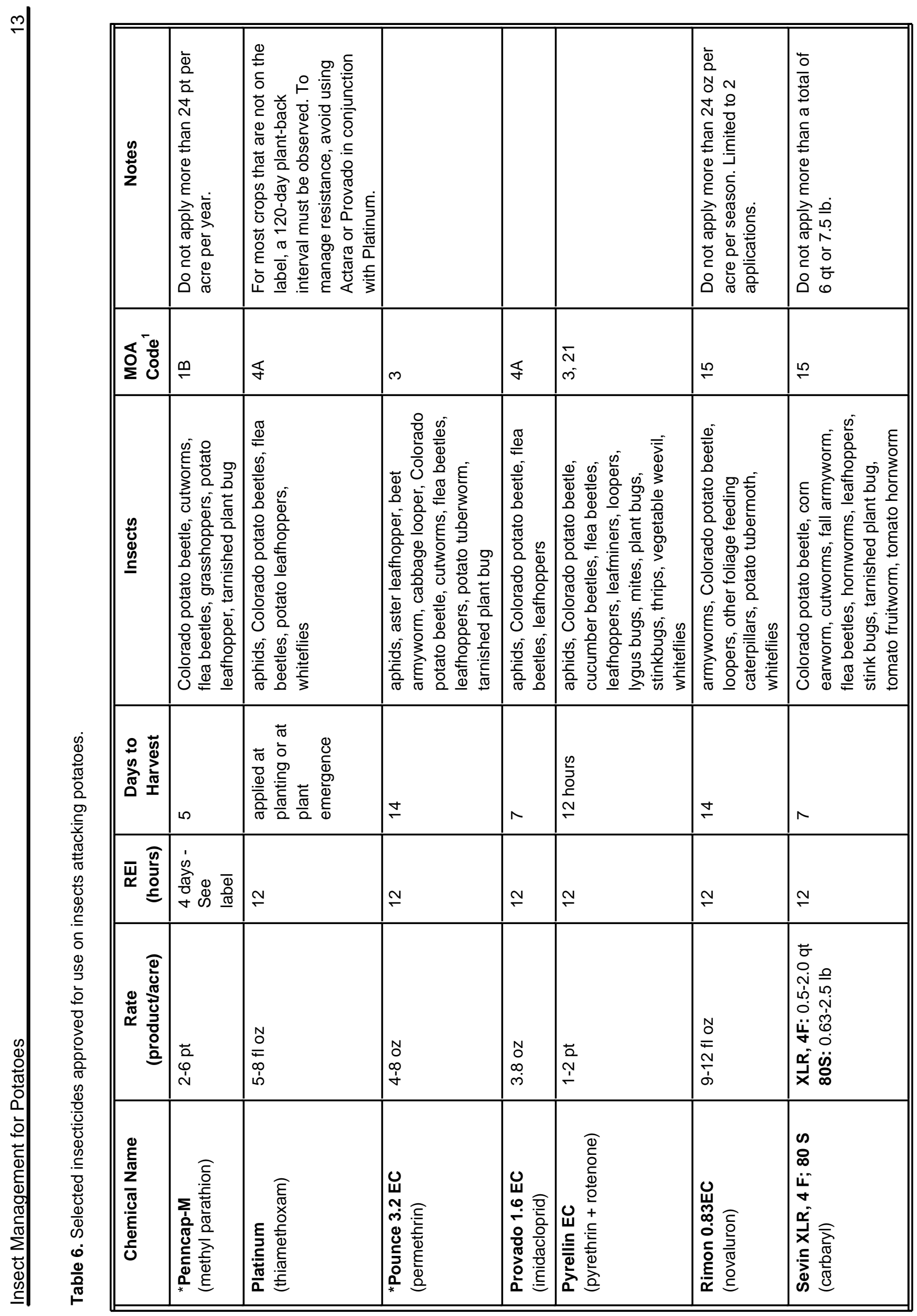




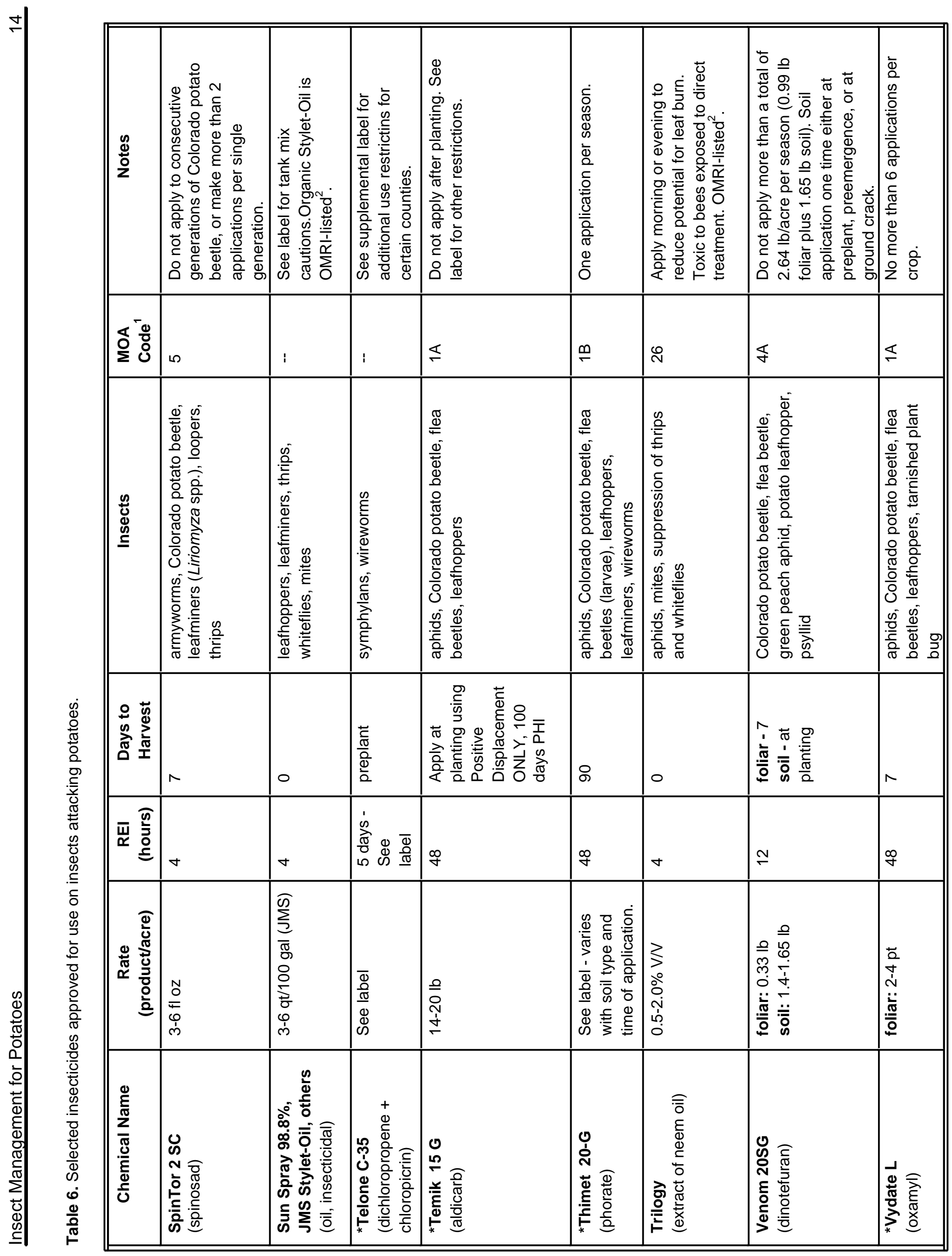




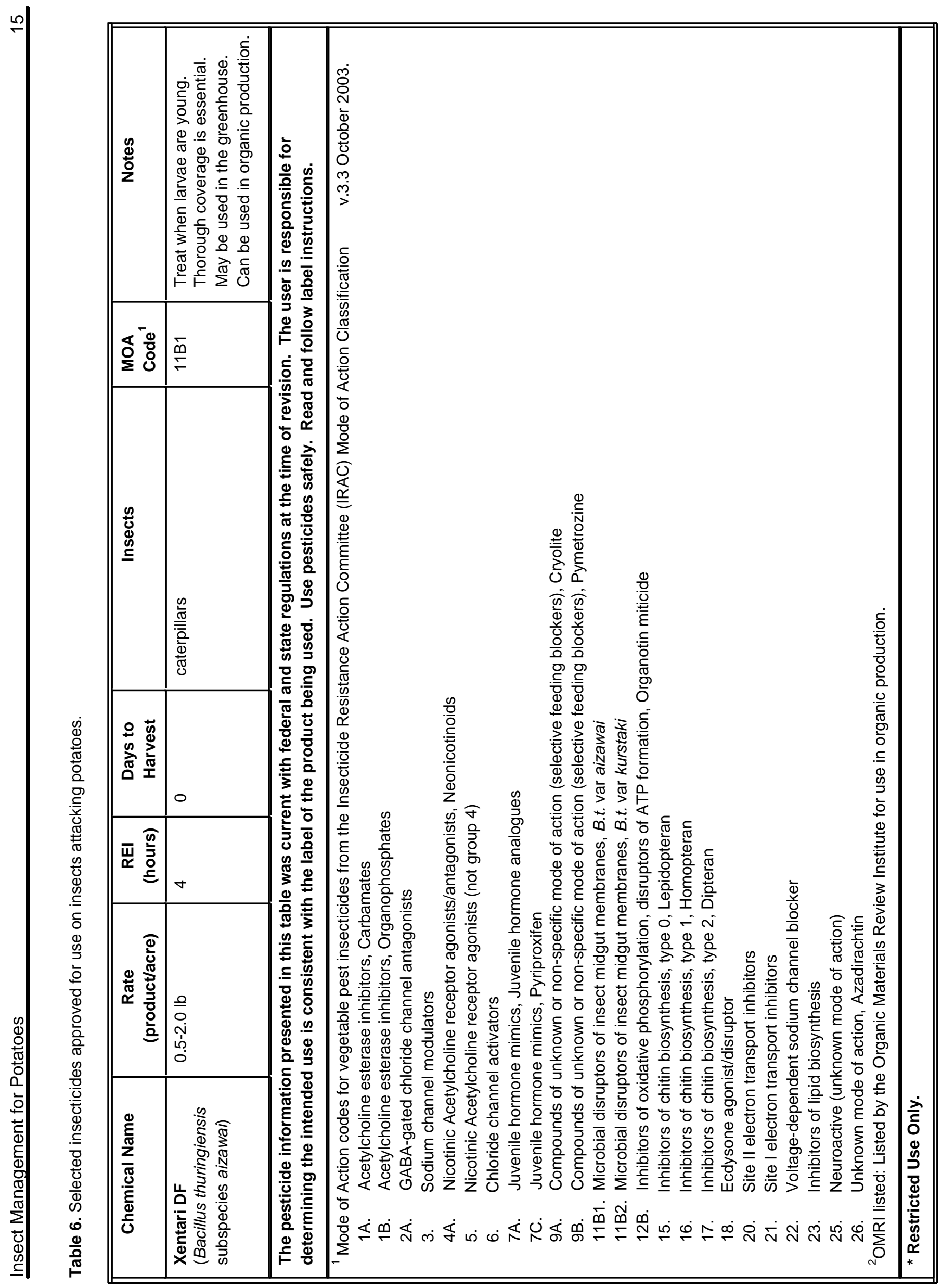

